\title{
PERBANDINGAN ASAS IKTIKAD BAIK: DALAM PERJANJIAN MENURUT SISTEM HUKUM CIVIL LAW (EROPA CONTINENTAL) DAN COMMON LAW (ANGLOSAXON)
}

\author{
Ariyanto \\ Advokat \& Kandidat Doktor \\ Fakultas Hukum Universitas Gadjah Mada Yogyakarta \\ Email : lawfirm93@gmail.com
}

\begin{abstract}
ABSTRAK
Prinsip iktikad baik ini mengandung makna berbeda-beda di antara sistem hukum. Pengertian dan pemahaman iktikad baik tampak berbeda khusunya di antara sistem hukum common law dan civil law. Menurut subekti, esensi (prinsip) ini merupakan salah satu sendi yang terpenting dalam hukum perjanjian. Iktikad baik tampak berbeda khususnya di antara sistem hukum common law dan sistem hukum civil law. Sekilas mengenai perbedaan antara civil law (Eropa Continental) dengan common law (Anglosaxon) dapat dilihat dari segi perkembangan keduanya. Perkembangan sistem civil law diilhami oleh para ahli hukum dalam menentukan atau membuat peraturan hukum secara sistematis dan utuh. Sedangkan perkembangan sistem common law terletak pada putusan-putusan hakim, yang bukan hanya menerapkan hukum tetapi juga menetapkan hukum.

Dalam sistem hukum common law arti iktikad baik tidak lain adalah "kejujuran" dalam perilaku atau kejujuran dalam bertransaksi dagang, termasuk di dalamnya adalah kejujuran dalam fakta dan penghormatan terhadap standar-standar dagang yang wajar dan transaksi dagang yang jujur. Sedangkan dalam civil law, iktikad baik itu diartikan, bahwa iktikad baik adalah suatu tindakan atau prilaku yang diharapkan dari seorang yang terhormat atau jujur yang diminta dalam setiap bentuk transaksi. Iktikad baik tersebut tidak hanya mengacu kepada iktikad baik para pihak, tetapi harus pula mengacu kepada nilai-nilai yang berkembang dalam masyarakat.
\end{abstract}

\section{Kata kunci : Prinsip itikad baik, comman law, civil law}

\section{ABSTRACT}

The principle of good faith implies vary among legal systems. Insight and understanding of different looks in good faith especially among the common law system and civil law. According subekti, essence (principle) is one of the most important joints in contract law. Good faith looked different, especially among the common law system and civil law system. Overview of the differences between civil law (Continental Europe) with common law (Anglo-Saxon) can be viewed in terms of the development of both. The development of civil law system inspired by legal experts in determining or making the rule of law in a systematic and intact. While the development of the common law system lies in the decisions of judges, which is not only applied the law but also laid down the law.

In a common law system sense of good faith is none other than "honesty" in behavior or honesty in trade transactions, including the honesty in fact and respect for the standards of fair trade and honest trade transactions. Whereas in civil law, is interpreted in good faith, that good faith is an act or behavior that is expected of a respectable or 
honest requested in any form of transaction. The good faith does not only refer to the good faith of the parties, but should also refer to the values that flourish in society.

Keywords: principle of good faith, comman law, civil law

\section{Pendahuluan}

Perkembangan hukum kontrak atau perjanjian di dalam praktik khususnya bisnis, termasuk juga perjanjian telah semakin pesat dan memiliki persoalan yang kompleks. Istilah hukum perjanjian atau kontrak merupakan terjemahan dari bahasa Inggris yaitu contract law, sedangkan dalam bahasa Belanda disebut dengan istilah overeenscomsrecht (Salim H.S, 2004). Suatu perjanjian adalah suatu peristiwa dimana seseorang berjanji kepada seorang lain atau dimana dua orang itu saling berjanji untuk melaksanakan sesuatu hal (Subekti, 1990). Sedangkan menurut Abdul Kadir Mohammad bahwa Perjanjian adalah suatu persetujuan dengan mana dua orang atau lebih saling mengikatkan diri untuk melakukan suatu hal dalam lapangan harta kekayaan (Mohammad, 1992). Dari peristiwa ini, timbullah suatu hubungan antara dua orang tersebut yang dinamakan perikatan. Dengan demikian perjanjian itu menerbitkan suatu perikatan antara dua orang yang membuatnya.

Dalam bentuknya, perjanjian itu berupa suatu rangkaian perkataan yang mengandung janji-janji atau kesanggupan yang diucapkan atau ditulis. Perjanjian bersumber dari perikatan. Perikatan adalah suatu perhubungan hukum antara dua orang atau dua pihak, berdasarkan yang mana pihak yang satu berhak menuntut sesuatu hal dari pihak yang lain, dan pihak yang lain berkewajiban untuk memenuhi tuntutan itu. Hubungan hukum dua pihak merupakan hubungan yang menimbulkan akibat hukum. Akibat hukum disebabkan karena timbulnya hak dan kewajiban, dimana hak merupakan suatu kenikmatan, sedangkan kewajiban merupakan beban. Maka hubungan hukum antara perikatan dan perjanjian adalah bahwa perjanjian itu menerbitkan perikatan.

Di dalam suatu perjanjian harus adanya iktikad baik. Norma iktikad baik ini merupakan salah satu sendi yang terpenting dari hukum perjanjian, demikian dikatakan Soebekti dan Vollmar (Adiwimarta, 1984). adapun yang dimaksud dengan perjanjian harus dilaksanakan dengan iktikad baik adalah bahwa perjanjian harus dilaksanakan menurut kepatutan dan keadilan (Setiawan, 1979).

Fakta hukum dalam sengketa pembatalan perjanjian ditenggarai sering dimanfaatkan oleh salah satu pihak dalam perjanjian (biasanya penggugat) dengan merancang dalildalil sedemikian rupa yang merasa kepentingannya dirugikan. Bahkan tidak jarang salah satu pihak dalam perjanjian kemudian meminta kepada hakim untuk menyatakan bahwa perjanjian tersebut batal demi hukum (void ab initio atau rechtswegenieteg) (Nindyo Pramono, 2010). Oleh sebab itu, suatu hal yang utama yang harus benar-benar diperhatikan oleh hakim dalam memeriksa dan memutus suatu perkara yang di dalamnya terhadap tuntutan pembatalan perjanjian adalah apakah benar penggugat beriktikad baik atau justru beriktikad buruk.

Secara teoritis menjadi hak seseorang untuk mengajukan gugutan apapun jika memang ia mempunyai alasan yang kuat untuk itu. Terbukanya kemungkinan untuk memohon 
pembatalan suatu perjanjian merupakan suatu sarana penting bagi suatu sistem hukum modern untuk menjamin terlaksananya prinsip-prinsip acces to justice atau akses kepada keadilan dan memastikan terjaganya prinsip rule of justice atau keadilan yang berkuasa. Karenanya, kemungkinan ini merupakan suatu hal yang lumrah dan bahkan wajib ada di negara-negara dengan sistem hukum yang modern dan demokratis. Hukum harus berfungsi sebagai pelindung kepentingan manusia. Dengan demikian, agar kepentingan manusia terlindungi maka hukum harus ditegakkan.

Asas yang berlaku dalam hukum perjanjian dipengaruhi oleh dua sistem hukum, yaitu sistem hukum civil law dan sistem hukum common law. Sistem hukum di Indonesia menganut sistem hukum civil law karena banyak dipengaruhi oleh Belanda mengenai ketentuan yang mengikat antara masyarakat dengan penguasa maupun masyarakat dengan masyarakat sendiri. Sedangkan Sistem common law bersumber dari hukum Inggris yang berkembang dari ketentuan atau hukum yang ditetapkan oleh Hakim (Judge) dalam keputusan-keputusan yang telah diambilnya (judge made law). Sistem hukum common law menganut asas hukum yang bernama the rule of precedent yaitu keputusan-keputusan hakim yang sudah ada harus dijadikan pegangan atau keputusan hakim itu harus mengikuti keputusan hakim sebelumnya. The rule of precedent sering disebut juga sebagai doktrin stare decisis yang berarti sebagai to stand by (previous)

decisions (berpegang/berpatokan pada putusan-putusan sebelumnya) (Hardijan Rusli, 1996).

Asas iktikad baik dalam perjanjian, dimaknai berbeda oleh negara-negara yang menganut sistem hukum common law dengan negara-negara yang menganut sistem hukum civil law. Dengan adanya perbedaan dalam penerapan asas iktikad baik di sistem hukum common law dengan sistem hukum civil law, maka penulis membuat rumusan masalah bagaimana perbandingan asas iktikad baik dalam perjanjian yang dianut di sistem hukum common law dengan sistem hukum civil law.

\section{Asas Iktikad Baik Perjanjian Dalam Sistem Hukum Common Law (ANGLOSAXON)}

Sistem hukum common law ini dianut oleh negara-negara yang berbahasa Inggris beserta dengan persemakmurannya, seperti negara Inggris, Amerika Serikat, Hongkong, India, Republik Irlandia, Pakistan, Sekendia Baru, Peranap, Kanada dan Australia. Kecuali negara bagian Lousiana di Amerika Serikat dan provinsi Quebec di Kanada yang menganut sistem hukumcivil law. Perkembangan sistem common law terletak pada putusan-putusan hakim, yang bukan hanya menerapkan hukum tetapi juga menetapkan hukum.

$$
\text { Madjedi Hasan mengatakan, }
$$
bahwa fokus perhatian dalam hukum perjanjian baik dalam common law umumnya diberikan pada tiga asas penting yang memilki keterjalinan satu sama lain, yakni asas konsensualisme, asas kekuatan yang mengikat, dan asas kebebasan berkontrak (Hasan, 2009). Dari berbagai pandangan yang dikemukakan, ternyata asas kebebasan berkontrak merupakan domain terpenting dalam hukum kontrak. Asas kebebasan berkontrak merupakan prinsip yang bersifat universal, karena diakui dalam sistem civil law dan common law, yang dalam perkembangannya cenderung dipenuhi dengan pembatasan-pembatasan. 
Diasumsikan, bahwa kebebasan tanpa batas akan cenderung terjadi penyalahgunaan dan perbuatan merugikan bagi satu pihak yang berada dalam posisi tawar yang lemah (Harnoko, 2008).

Dalam berbagai sistem hukum, bangunan hukum kontrak didirikan di atas landasan aturan yang bersifat heteronom yang dikeluarkan negara maupun otonom yang didasarkan atas kesepakatan para pihak. Kesepakatan yang dicapai dalam kontrak mempunyai kedudukan dan karena itu memilki kekuatan mengikat sama seperti undang-undang. Selanjutnya, setiap pelaksanan kontrak harus dilakukan dengan iktikad baik. Perjanjian atau kontrak tersebut tidak dapat ditarik kembali, selain dengan sepakat kedua belah pihak atau karena alasan-alasan yang oleh undang-undang dinyatakan cukup untuk itu. Kontrak harus dilaksanakan dengan iktikad baik. Perlu dikemukakan lebih dahulu, bahwa meskipun sebagian sarjana menempatkan kontrak dalam makna yang lebih sempit, karena ditujukan kepada perjanjian yang tertulis saja (Subekti, 1979), namun dalam kesempatan ini perkatan kontrak dan perjanjian ditempatkan dalam arti yang sama (Ahmadi Miru, 2007).

Pada negara yang didominasi oleh sistem hukum common law asas perjanjiannya bertumpu pada kepastian dan prediktibiltitas, sehingga lebih cenderung menggunakan asas kebebasan berkontrak. Asas kebebasan berkontrak merupakan asas dimana orang bebas untuk membuat atau tidak membuat perjanjian, bebas menentukan isi, berlakunya dan syarat-syarat perjanjian, dengan bentuk tertentu atau tidak dan bebas perjanjian itu (Purwahid Patrik, 1986). Dalam hukum Inggris, asas ini dikenal dengan (Mariam Darus , 2001)
" A promise more than a mere statement of intention for it imports a willingness on the part of the promise to be bound to the person to whom it is made"

Menurut Sudikno Mertokusumo, bahwa kontrak atau perjanjian sebagai perbuatan hukum yang bersisi dua (een tweezijdige overeenkomst) yang didasarkan kata sepakat untuk menimbulkan akibat hukum. Walaupun dengan adanya kata sepakat dari kedua belah pihak dalam perjanjian, tidak dapat dipungkiri bahwa dalam pelaksanaan kontrak atau perjanjian harus didasarkan dengan asas iktikad baik.

Iktikad baik dalam kontrak merupakan asas yang paling penting, namun menimbulkan banyak penafsiran yang berbeda pada setiap negara. Seperti halnya negara yang menganut sistem hukum common law yang melihat iktikad baik bukan dimulai dari prakontrak melainkan dari isi kontrak. Padahal dalam perjanjian atau kontrak, Iktikad baik pada tahap prakontrak merupakan kewajiban untuk memberitahukan atau menjelaskan dan meneliti fakta material bagi para pihak yang berkaitan dengan pokok yang dinegosiasikan itu. Tetapi hal ini berbeda dengan sistem hukum di common law. Di dalam menghadapi ketidakrasionalan dan ketidakpatutan baik dalam negosiasi dan penyusunan kontrak, di negara-negara dengan sistem common law tidak selamanya dianut perluasan iktikad baik ke dalam hubungan prakontrak.

Hukum di negara Amerika Serikat (AS) berpendapat bahwa iktikad baik hanya ada setelah kontrak ditandatangani. Dalam sistem common law, arti iktikad baik tidak lain adalah "kejujuran" dalam perilaku atau kejujuran dalam bertransaksi dagang, termasuk di dalamnya adalah kejujuran 
dalam fakta dan penghormatan terhadap standar-standar dagang yang wajar dan transaksi dagang yang jujur. Kejujuran dalam pelaksanaan perjanjian terletak pada keadaan jiwa manusia, akan tetapi titik berat dari kejujuran ini terletak pada tindakan yang dilakukan kedua belah pihak dalam hal melaksanakan janji. Dalam melaksanakan tindakan inilah kejujuran harus berjalan dalam hari sanubari seorang manusia berupa selalu mengingat, bahwa manusia itu sebagai anggota masyarakat harus jauh dari sifat menipukan pihak lain dengan menggunakan secara membabi buta kata-kata yang dipakai pada waktu kedua belah pihak membentuk suatu persetujuan. Kedua belah pihak harus selalu memperhatikan hal ini dan tidak boleh mempergunakan kelalaian pihak lain untuk menguntungkan diri pribadi (Prodjodikoro, 1983).

Sama halnya dengan hukum di negara Inggris, tidak mengenal proses negosiasi, para pihak tidak terikat oleh prinsip beriktikad baik. Menurut hukum inggris, masuknya para pihak ke dalam negosiasi tidak dengan serta merta melahirkan kewajiban iktikad baik. Menurut hukum inggris, selama kontrak belum ditandatangani, para pihak tidak terikat satu sama lain dan tidak memiliki kewajiban apapun terhadap pihak lainnya hingga kontrak tersebut akhirnya ditandatangani (Grace Xavier, 2004).

Secara tradisonal hukum kontrak common law tidak mengakui keberadaan suatu kewajiban (kontraktual) hingga proses negosiasi telah mengkristal dalam pembentukan kontrak. Salah satu pihak yang mengadakan negosiasi setiap saat dapat menghentikan negosiasi tersebut dengan alasan apa pun juga tanpa adanya suatu tanggung jawab. Tidak ada kewajiban untuk bertanggungjawab terhadap kerugian yang timbul atas segala biaya dikeluarkan dan keuntungan yang diharapkan akibat penghentian negosiasi dalam fase prakontrak ini. Hukum kontrak common law Inggris masih belum dapat menerima kewajiban bahwa negosiasi kontrak harus didasarkan pada iktikad baik (A.F. Mason, 2002; Ridwan, 2010).

Hukum kontrak Inggris secara tradisional menolak pembebanan kewajiban menjelaskan dalam negosiasi dan penyusunan kontrak. Di dalam sistem hukum common law, Asas caveat emptor (Shidarta, 2006) masih menjadi salah satu asas yang fundamental. Hanya ada beberapa pengecualian terhadap asas tersebut, seperti kontrak ubrrimae fidei atau dalam kondisi tertentu yang secara tegas diwajibkan oleh undang-undang. Sistem hukum Common law mengikuti asas caveat emptor yang berkembang dalam kontrak jual beli pada abad Sembilan belas. Dalam kasus Smith v. Hughes dinyatakan bahwa tidak ada kewajiban hukum bagi vendor untuk memberitahukan kekeliruan pembeli yang tidak disebabkan perbuatan vendor. Dengan demikian, secara umum tidak ada dasar iktikad baik yang mewajibkan salah satu pihak dalam kontrak untuk menjelaskan fakta material ketika akan mengadakan kontrak (Ridwan Khairandy).

Dalam common law Inggris dikenal dua makna itikad baik yang berbeda, yakni good faith performance dan good faith purchase. Good faith performance berkaitan dengan kepatutan (yang objektif), atau reasonableness pelaksanaan kontrak. Di dalam makna yang demikian itu, itikad baik digunakan sebagai implide term, yang digunakan dalam hukum Romawi, mensyaratkan adanya kerjasama diantara para pihak untuk tidak menimbulkan kerugian dari 
reasonableness expectation. Good faith purchase, di lain pihak, berkaitan dengan a contracting party's subjective state of mind; apakah seseorang membeli dengan itikad baik sepenuhnya digantungkan pada ketidaktauannya, kecurigaan, dan pemberitahuan yang berkaitan dengan kontrak.

Dalam penerapakan asas iktikad baik yang dianut oleh sistem hukum common law ini, tidak terlepas dari adanya kekurangan-kekurangan dan kelebihan-kelebihan yang dianut oleh setiap Negara. Kekurangan dari penerapan asas iktikad baik dalam sistem hukum common law hanya menerapkan iktikad baik pada tahap pelaksanaan kontrak saja (dengan melihat isi kontrak). Padahal dalam perjanjian atau kontrak, iktikad baik pada tahap prakontrak itu sangat penting untuk memberitahukan atau menjelaskan dan meneliti fakta material bagi para pihak yang berkaitan dengan pokok yang dinegosiasikan itu. Dalam pelaksanaan tahap prakontrak ini, apabila salah satu pihak membatalkan sepihak perjanjian tersebut maka ia dapat dikenai ganti kerugian. Dengan adanya penawaran dan permintaan, dalam tahap prakontrak ini masingmasing pihak harus menegakkan prinsip itikad baik, yang oleh karena itu jika salah satu pihak beriktikad buruk, maka haruslah disediakan sarana hukum berupa hak gugat dan hak untuk menuntut ganti rugi dalam tahap prakontrak. Jika hanya menerapkan fase pelaksanaan kontrak saja, maka tuntutan ganti kerugian dari salah satu pihak yang membatalkan perjanjian hanya sebatas pada isi kontrak bukan dari tahap prakontrak.

Kelebihan diterapkannya asas iktikad baik dilihat dari isi kontrak dalam sistem hukum common law, hal ini untuk menghindari adanya salah satu pihak yang mengadakan negosiasi yang setiap saat dapat menghentikan negosiasi tersebut dengan alasan apa pun juga tanpa adanya suatu tanggung jawab. Menurut sistem hukum common law, tidak ada kewajiban untuk bertanggungjawab terhadap kerugian yang timbul atas segala biaya dikeluarkan dan keuntungan yang diharapkan akibat penghentian negosiasi dalam fase prakontrak ini. Selama kontrak belum ditandatangani dalam bentuk isi kontrak, maka para pihak tidak terikat satu sama lain dan tidak memiliki kewajiban apapun terhadap pihak lainnya hingga kontrak tersebut akhirnya ditandatangani.

\section{Asas Iktikad Baik Perjanjian Dalam Sistem Hukum Civil Law (Eropa Continental)}

Perkembangan

sistem civil law diilhami oleh para ahli hukum dalam menentukan atau membuat peraturan hukum secara sistematis dan utuh. Iktikad baik (good faith) dalam pelaksanaan kontrak merupakan lembaga hukum (rechtsfiguur) yang berasal dari hukum Romawi yang kemudian diserap oleh civil law. Karena prinsip iktikad baik di negara-negara Civil Law banyak dipengaruhi tradisi hukum Romawi dan Kanonik. doktrin iktikad baik dalam hukum Romawi berkembang seiring dengan diakuinya kontrak konsensual yang pada mulanya hanya meliputi kontrak jual-beli, sewamenyewa, persekutuan perdata dan mandate (Alan Watson, 1995). Doktrin iktikad baik berakar pada etika sosial Romawi mengenai kewajiban yang komprehensif akan ketaatan dan keimanan yang berlaku bagi warga negara maupun bukan (Martin Joseph Schermaier).

Iktikad baik dalam hukum kontrak Romawi mengacu kepada tiga bentuk perilaku para pihak dalam kontrak. Pertama, para pihak harus 
memegang teguh janji atau perkataannya, kedua, para pihak tidak boleh mengambil keuntungan dengan tindakan yang menyesatkan terhadap salah satu pihak. Ketiga, para pihak mematuhi kewajibannya dan berprilaku sebagai orang terhormat dan jujur, walaupun kewajiban tersebut tidak secar tegas diperjanjikan (Razaq Faraid).

Perkembangan iktikad baik dalam hukum Romawi tidak lepas kaitannya dengan evolusi hukum kontrak itu sendiri. Pada mulanya hukum Romawi hanya mengenal iudiciastricti iuris, yakni kontrak yang lahir dari perbuatan menurut hukum (negotium) yang secara ketat dan formal mengacu ke ius civile. Apabila hakim menghadapi kasus kontrak semacam itu, ia harus memutusnya sesuai dengan hukum. Hakim terikat kepada apa yang secara tegas dinyatakan dalam kontrak (express term). Berikutnya berkembang iudicia bonae fidei. Perbuatan hukum yang didasarkan iudicia bonae fidei disebut negotia bonae fidei. Konsep negotia berasal dari ius gentium yang mensyaratkan pihak-pihak yang membuat dan melaksanakan kontrak harus sesuai dengan iktikad baik (Warmelo, 1976).

Dapat terlihat bahwa pengadilan di Romawi selain mengakui keberadaan atau kekuatan hukum kontrak konsensual, pada saat yang sama juga membebankan adanya kewajiban iktikad baik bagi para pihak. Jika seorang tergugat melakukan wanprestasi dalam suatu kontrak konsensual, dia langsung dapat digugat ke pengadilan oleh Penggugat atas dasar melanggar kewajiban iktikad baik (Anderson, 1995).

Sistem hukum civil law bertumpuh pada tujuan hukum keadilan, maka tidak mengherankan jika asas yang mencolok di sini adalah asas itikad baik, dan kesepakatan (Pacta Sun Servanda).
Pada mulanya pengadilan memegang teguh asas pacta sunt servanda, tetapi belakangan sikap ini bergeser ke arah kepatutan atau iktikad baik. Iktikad baik bahkan kemudian digunakan hakim untuk membatasi atau meniadakan kewajiban kontraktual apabila ternyata isi dan pelaksanaan perjanjian bertentangan dengan keadilan.

Tidak seperti pengadilan common law yang secara tradisional memiliki kewajiban untuk menafsirkan kontrak berdasarkan isi kontrak untuk menentukan maksud para pihak, hakim dan sarjana hukum Romawi memiliki tanggung jawab untuk menentukan apakah para pihak telah bertindak sesuai dengan iktikad baik. Inti hukum kontrak Romawi adalah ketentuan (maksim) Pacta sunt servanda, yang dijadikan ketentuan dasar iktikad baik. Dengan demikian para pihak tidak hanya terikat pada isi perjanjian (term) yang secara jelas disepakati, tetapi juga kepada semua isi yang naturally implied dalam perjanjian (Ridwan Khairandy, 2003).

Di negara-negara maju yang menganut civil law sistem, pengadilan memberlakukan asas itikad baik bukan hanya dalam tahap penandatanganan dan pelaksanaan saja tetapi juga dalam tahap perundingan. Iktikad baik dalam kontrak dibedakan antara iktikad baik prakontrak (precontractual good faith) dan iktikad baik pelaksanaan kontrak (good faith on contract performance). Iktikad baik di dalam fase prakontrak disebut juga sebagai iktikad baik subjektif. Iktikad baik prakontrak, adalah iktikad yang harus ada saat para pihak melakukan negosisasi. Iktikad baik prakontrak bermakna kejujuran (honesty). Iktikad baik ini disebut iktikad yang bersifat subjektif, karena didasarkan pada kejujuran para pihak yang melakukan negosiasi. Sedangkan iktikad baik dalam fase pelaksanaan 
kontrak disebut iktikad baik obyektif. Iktikad baik pelaksanaan kontrak yang disebut sebagai iktikad baik objektif mengacu kepada isi perjanjian. Isi perjanjian harus rasional dan patut. Isi kontrak adalah kewajiban dan hak para pihak yang mengadakan kontrak, kewajiban dan hak tersebut harus rasional dan patut (Ridwan Khairandy).

Bentuk iktikad baik dalam hukum kontrak romawi bermakna bahwa iktikad baik adalah suatu tindakan atau prilaku yang diharapkan dari seorang yang terhormat atau jujur yang diminta dalam setiap bentuk transaksi. Iktikad baik tersebut tidak hanya mengacu kepada iktikad baik para pihak, tetapi harus pula mengacu kepada nilai-nilai yang berkembang dalam masyarakat (Ridwan Khairandy). Pencantuman kewajiban iktikad baik di dalam kontrak yang diatur di Pasal 1134 ayat (3) Civil Code Perancis yang menyatakan bahwa kontrak harus dilaksanakan dengan iktikad baik (contract doivent etre executes de bonna foi). Makna umum iktikad baik di sini mengacu kepada standar perilaku yang reasonable yang tidak lain bermakna bahwa orang harus mematuhi janji atau perkataannya dalam segala keadaan.

Di dalam Kitab Undang-Undang Hukum Perdata Belgia, negara ini msyaratkan semua kontrak dilaksanakan dengan iktikad baik baik dan penafsiran (kontraktualnya) pun harus disertai dengan kebiasaan. Dalam hukum Belgia, Perancis serta Venezuela hubungan prakontraktual umumnya diletakkan pada perbuatan melawan hukum. Di beberapa negara seperti Cheko dan Belanda hubungan kontrak tidak terlalu diperhatikan. Hal yang sama juga terjadi di Jepang, dalam yurisprudensi Jepang dijumpai bahwa kadang hubungan hukum dalam prakontraktual didasarkan pada perbuatan melawan hukum dan kadang pula didasarkan pada kontrak pendahuluan atau Quasi kontrak (Ridwan Khairandy).

Di beberapa negara dengan sistem civil law, seperti Italia telah memiliki ketentuan legislasi yang mewajibkan negosiasi dan penyusunan kontrak harus dilakukan dengan iktikad baik. Asas iktikad baik dapat disimpulkan dari Pasal 1338 ayat (3) KUHPerdata yang berbunyi "Perjanjian harus dilaksanakan dengan itikad baik". Asas iktikad baik merupakan asas dimana para pihak dalam kontrak harus melaksanakan substansi kontrak berdasarakan kepercayaan atau keyakinan teguh atau kemauan baik dari para pihak. Asas iktikad baik dibagi menjadi dua, yaitu iktikad baik nisbi dan iktikad baik mutlak. Dalam iktikad baik nisbi, orang memperhatikan sikap dan tingkah laku yang nyata dari subjek, sedang iktikad baik mutlak merupakan penilaiannya terletak pada akal sehat dan keadilan, dibuat ukuran yang objektif untuk menilai keadaan. Berdasarkan asas iktikad baik, maka para pihak dalam kontrak harus melaksanakan substansi kontrak berdasarkan kepercayaan atau keyakinan teguh atau kemauan baik dari para pihak. Kontrak harus dilaksanakan menurut kepatutan dan keadilan (Salim HS, 2008).

Iktikad baik subjektif (subjectieve goede trouw) dikaitkan dengan hukum benda (bezit). Disini ditemukan istilah pemegang yang beriktikad baik atau pembeli barang yang beriktikad baik dan sebagainya seb agai lawan dari orangorang yang berikti kad buruk. Seorang pembeli yang beriktikad baik adalah seseorang yang membeli barang dengan penuh kepercayaan bahwa si penjual benarbenar pemilik dari barang yang dijualnya itu. Ia sama sekali tidak mengetahui bahwa ia membeli barang 
dari orang yang bukan pemiliknya. Ia adalah seorang pembeli yang jujur. Dalam hukum benda, iktikad baik diartikan sebagai kejujuran. Pembeli yang beriktikad baik adalah orang yang jujur yang mengetahui adanya cacat yang melekat pada barang yang dibelinya itu. Artinya cacat mengenai asal usulnya. Dalam hal ini, iktikad baik merupakan suatu elemen subjektif (Subekti, 1984). Iktikad baik yang subjektif ini berkaitan dengan sikap batin atau kejiwaan (psychische gestelheid), yakni apakah yang bersangkutan menyadari atau mengetaui bahwa tindakannya bertentangan

atau tidak iktikad baik.

Iktikad baik dalam pelaksanaan kontrak mengacu kepada iktikad baik yang objektif. Standar yang digunakan dalam iktikad baik objektif adalah standar yang objektif yang mengacu kepada suatu norma yang objektif. Perilaku para pihak dalam kontrak harus diuji atas dasar norma-norma objektif yang tidak tertulis yang berkembang di dalam masyarakat. Ketentuan iktikad baik menunjuk kepada norma-norma tidak tertulis yang sudah menjadi norma hukum sebagai suatu sumber hukum tersendiri. Norma tersebut dikatakan objektif karena tingkah laku tidak didasarkan pada anggapan para pihak sendiri, tetapi tingkah laku tersebut harus sesuai dengan anggapan umum tentang iktikad baik tersebut (Razaq Faraid).

Berbagai putusan Hoge Raad (HR) yang erat kaitannya dengan penerapan asas itikad baik dapat diperhatikan dalam kasus-kasus posisi berikut ini. Kasus yang paling menonjol adalah kasus Sarong Arrest. Kasus arrest ini berkaitan dengan turunnya nilai uang (devaluasi) Jerman setelah Perang Dunia I Salim). Kasus Sarong Arrest, Pada tahun 1918 suatu firma Belanda memesan pada pengusaha Jerman sejumlah sarong dengan harga sebesar 100.000 gulden. Karena keadaan memaksa sementara, penjual dalam waktu tertentu tidak dapat menyerahkan pesanan. Setelah keadaan memaksa berakhir, pembeli menuntut pemenuhan prestasi. Tetapi sejak diadakan perjanjian keadaan sudah banyak berubah dan penjual bersedia memenuhi pesanan tetapi dengan harga yang lebih tinggi, sebab apabila harga tetap sama maka penjual akan menderita kerugian, yang berdasarkan itikad baik antara para pihak tidak dapat dituntut darinya.

Pembelaan yang penjual ajukan atas dasar Pasal 1338 ayat (3) KUHPerdata dikesampingkan oleh HR dalam arrest tersebut. Menurut putusan HR tidak mungkin satu pihak dari suatu perikatan atas dasar perubahan keadaan bagaimanapun sifatnya, berhak berpatokan pada itikad baik untuk mengingkari janjinya yang secara jelas dinyatakan HR masih memberi harapan tentang hal ini dengan memformulasikan, mengubah inti perjanjian atau mengesampingkan secara keseluruhan. Hal ini tidak dapat diharapkan suatu putusan yang lebih ringan, jika hal itu bukan merupakan perubahan inti atau mengesampingkan secara keseluruhan. Putusan HR ini selalu berpatokan pada saat dibuatnya oleh para pihak. Apabila pihak pemesan sarong sebanyak yang dipesan maka penjual harus melaksanakan isi perjanjian tersebut, karena didasarkan bahwa perjanjian harus dilaksanakan dengan itikad baik.

Dalam perkembangannya, kelebihan dan kekurangan dalam penerapan asas iktikad baik yang dianut oleh sistem hukum civil law ini yaitu, dengan adanya tahap prakontrak ini masing-masing pihak harus menegakkan prinsip itikad baik di awal 
kesepakatan, yang oleh karena itu jika salah satu pihak beritikad buruk, maka haruslah disediakan sarana hukum berupa hak gugat dan hak untuk menuntut ganti rugi dalam tahap prakontrak. Pada tahap prakontrak, apabila salah satu pihak membatalkan sepihak perjanjian tersebut, maka ia dapat dikenai ganti kerugian. Namun hanya sebatas pada kerugian yang timbul saat tahap perjanjian prakontrak saja. Jelas disini yang ada baru negosiasi prakontrak, belum ada perikatannya. Penuntutan hanya dapat dilakukan dengan menggunakan prinsip good faith dan fair dealing yang dapat ditafsirkan bahwa pihak yang dirugikan hanya dapat menuntut pengembalian atas biaya yang telah dikeluarkan dan atas kehilangan kesempatan untuk melakukan kontrak dengan pihak ketiga. Selain itu juga dengan adanya fase prakontrak, tujuannya untuk memperkecil kemungkinan terjadinya permasalahan hukum dikemudian hari, maka saat-saat negosiasi menjadi sangat penting untuk dapat mengemukakan keinginan masing-masing pihak sebelum kontrak itu dibuat. Dengan diterapkannya asas iktikad baik pada fase pelaksanaan kontrak, maka ia dapat menuntut ganti rugi atas keuntungan yang diharapkan dari isi kontrak yang batal diadakan tersebut.

\section{Simpulan}

Prinsip iktikad baik ini mengandung makna berbeda-beda di antara sistem hukum. Pengertian dan pemahaman iktikad baik tampak berbeda khusunya di antara sistem hukum common law dan civil law. Menurut subekti, esensi (prinsip) ini merupakan salah satu sendi yang terpenting dalam hukum perjanjian. Iktikad baik tampak berbeda khususnya di antara sistem hukum common law dan sistem hukum civil law. Sekilas mengenai perbedaan antara civil law (Eropa Continental) dengan common law (Anglosaxon) dapat dilihat dari segi perkembangan keduanya. Perkembangan sistem civil law diilhami oleh para ahli hukum dalam menentukan atau membuat peraturan hukum secara sistematis dan utuh. Sedangkan sistem common law terletak pada putusan-putusan hakim, yang bukan hanya menerapkan hukum tetapi juga menetapkan hukum.

Dalam sistem hukum common law arti iktikad baik tidak lain adalah "kejujuran" dalam perilaku atau kejujuran dalam bertransaksi dagang, termasuk di dalamnya adalah kejujuran dalam fakta dan penghormatan terhadap standar-standar dagang yang wajar dan transaksi dagang yang jujur. Sedangkan dalam civil law, iktikad baik itu diartikan, bahwa iktikad baik adalah suatu tindakan atau prilaku yang diharapkan dari seorang yang terhormat atau jujur yang diminta dalam setiap bentuk transaksi. Iktikad baik tersebut tidak hanya mengacu kepada iktikad baik para pihak, tetapi harus pula mengacu kepada nilai-nilai yang berkembang dalam masyarakat.

Negara yang menganut sistem hukum common law, melihat iktikad baik bukan dimulai dari fase prakontrak melainkan dari fase pelaksanaan kontrak ( isi kontrak). Pada fase pelaksanaan kontrak ini sering disebut sebagai iktikad baik obyektif. Iktikad baik pelaksanaan kontrak yang disebut sebagai iktikad baik objektif yang lebih mengacu kepada isi perjanjian. Berbeda halnya dengan sistem hukum civil law. Dalam sistem hukum civil law, pendekatan terhadap filosofi dari kontrak yang menitikberatkan atau memusatkan pada hubungan para pihak. Hubungan ini mensyaratkan kewajiban iktikad baik bukan saja 
ketika kontrak ditandatangani, tetapi juga sebelum kontrak ditutup yaitu pada saat negosiasi.

Hukum di negara dengan sistem civil law pada umumnya ditujukan untuk menetapkan suatu kaidah atau norma yang berada di suatu lingkungan masyarakat untuk diikuti dan dipatuhi oleh masyarakat itu sendiri. Dengan demikian, hukum merupakan bagian integral dari kehidupan bersama yang mengatur dan menguasai sesama manusia. Jadi dapat dikatakan hukum terdapat dalam masyarakat manusia sehingga dalam setiap masyarakat selalu ada sistem hukum.

Menurut penulis, penerapan asas iktikad baik, sebaiknya dilihat secara utuh mulai dari fase prakontrak dan fase pelaksanaan kontrak. Karena asas itikad baik ini harus memberikan atau mencerminkan prinsip kemanfaatan (beneficence) yang diterjemahkan sebagai keharusan berbuat baik (bona fidel), bahwa hidup bersama harus mendatangkan kemanfaatan (kemashlahatan) dan sekali-kali tidak boleh merugikan orang lain. Setiap orang wajib membantu orang lain atau bekerjasama dalam memenuhi tuntutan kebutuhannya sebagai subjek hukum. Hal ini dikarenakan erat kaitannya dengan prinsip keadilan (justice) yang diterjemahkan sebagai prinsip saling menguntungkan. Prinsip justice ini menuntut agar setiap orang diperlakukan secara sama sesuai dengan aturan yang adil dan sesuai kriteria obyektif, serta dapat dipertanggungjawabkan.

Jika hanya berpacu pada prinsip prakontrak saja, maka tanpa adanya isi kontrak akan sulit dalam pembuktian jika terjadi wanprestasi karena iktikad buruk oleh salah satu pihak. Isi kontrak dapat menjadi pelindung bagi para pihak dalam menjalankan kerjasama.
Dalam tahapan penyusunan kontrak juga akan diperoleh manfaat mengenai terangnya hak dan kewajiban para pihak dalam penyelenggaraan kerjasama yang dimaksud. Dengan mengikuti seluruh tahapan penyusunan kontrak, termasuk negosiasi maka para pihak akan lebih saling mengenal potensi masing-masing dan akan dapat saling memanfaatkan dengan prinsipprinsip yang sehat demi tercapainya keuntungan bersama.

Oleh karena itu, demi menegakkan kepastian hukum dan keadilan agar memberi kemanfaatan bagi para pencari keadilan yang mengadukan sengketa hukum mereka kepada hakim, hakim dituntut untuk mampu secara arif dan bijaksana menegakkan hukum dengan selalu memperhatikan tiga tungku hukum : kepastian hukum (rechtssicherheit), kemanfaatan (zweckmabigkeit), dan keadilan (gerechtigkeit) (Soedikno Mertokusumo, 1984; Satrio, 2001).

Riduan Syahrani menyebutkan bahwa dalam rangka pelaksanaan perjanjian peranan iktikad baik (te geder trouw) sungguh mempunyai arti yang sangat penting sekali. Pemikiran ini berpijak dari pemahaman bahwa iktikad baik merupakan landasan dalam melaksanakan perjanjian dengan sebaik-baiknya dan semestinya (Riduan Syahrani, 2000). Asas iktikad baik menjadi salah satu instrument hukum untuk membatasi kebebasan berkontrak dan kekuatan mengikatnya perjanjian.

Dalam hukum kontrak iktikad baik memiliki tiga fungsi yaitu, fungsi yang pertama, semua kontrak harus ditafsirkan sesuai dengan iktikad baik, fungsi kedua adalah fungsi menambah yaitu hakim dapat menambah isi perjanjian dan menambah peraturan perundang-undangan yang berkaitan dengan perjanjian itu. Sedangkan fungsi ketiga adalah fungsi membatasi dan 
meniadakan en derogerende werking vande geode trouw). Dengan fungsi ini hakim dapat mengenyampingkan isi perjanjian yang telah dibuat oleh para pihak.

\section{Daftar Pustaka}

A. Madjedi Hasan, 2009, Kontrak Minyak Dan Gas Bumi Berazas Keadilan Dan Kepastian Hukum, Jakarta, Fikahati Aneska.

A.F. Mason, "Contract, Good Faith and Equitable Standards in Fair Dealing", The Law Qurterly Review, Vol. 116 Januari 2000.

Abdul Kadir Mohammad, 1992, Hukum Perikatan, Bandung, Citra Aditya Bhakti.

Agus Yudha Harnoko, 2008, Hukum Perjanjian, Asas Proporsionalitas Dalam Kontrak Komersial, Yogyakarta, LaksBang Mediatama..

Ahmadi Miru, 2007, Hukum Kontrak dan Perancangan Kontrak, Jakarta, Raja Grafindo Persada.

Alan Watson, 1995, Roman Law \& Commerce, University of Georgia Press, Athens.

Budiono Kusumohamidjojo, 2001, Panduan Untuk Merancang Kontrak, Jakarta, Grasindo.

Fikra Abdul Razaq Faraid, "Hukum Perikatan", Fakultas Hukum Universitas Krisna Dwi Payana, Jakarta.

Grace Xavier, "Global Harmonization of Contract Laws Pact or Fiction?" Contruction Law Journal, Vol. 20, NO. 1, 2004.

Hardijan Rusli, Hukum Perjanjian Indonesia dan Common Law, Ctk. Kedua, Jakarta, Pustaka Sinar Harapan, 1996.

I. S. Adiwimarta, 1984, Pengantar Studi Hukum Perdata II, Jakarta, Rajawali.
J. Satrio, 2001, Hukum Perikatan, Perikatan Yang Lahir Dari Perjanjian, Bandung, Citra Aditya Bakti.

Jill Pride Anderson, 1995, "Lender Liability for Breach of the Obligation of Good Faith Performance", Roman Law \& Comparative Law, Athens, University of Georgia Press.

Mariam Darus Badrulzaman, dkk, 2001, Kompilasi Hukum Perikatan, Bandung, PT Citra Adtya Bakti.

Martin Joseph Schermaier, Bona Fides in Roman Contract $L$ $a w$, Reinhard Zimmerman dan Simon Whittaker, eds.

Nindyo Pramono, "Problematika Putusan Hukum Dalam Perkara Pembatalan Perjanjian". Mimbar Hukum Volume 22 No. 2, Juni 2010.

P. van Warmelo, 1976, An Introduction to the Principles of Roman Law, Juta and Co Ltd, Cape Town.

Purwahid Patrik, 1986, Asas Iktikad Baik dan Kepatutan Dalam Perjanjian, Ctk. Pertama, Semarang, Fakultas Hukum UNDIP.

R. Setiawan, 1979, Pokok-Pokok Hukum Perikatan, Bandung, Binacipta.

R. Subekti, 1984, Hukum Perjanjian, Jakarta, Intermasa.

R.Wirjono Prodjodikoro, 1983, Azasazas Hukum Perdata, Bandung, Sumur.

Riduan Syahrani, 2000, Seluk Beluk dan Azas-azas Hukum Perdata, Bandung, Alumni.

Ridwan Khairandy, Hukum Kontrak Indonesia Dalam Perspektif Perbandingan (Bagian Pertama), Ctk. Pertama, Yogyakarta, FH UII Press. Dalam 2003, Iktikad Baik 
Jakarta, Fakultas Hukum Universitas Indonesia, Jakarta.

Salim H.S, 2004, Hukum Kontrak: Teori \& Teknik Penyusunan Kontrak, Ctk. Kedua, Jakarta, Sinar Grafika.

Salim HS,dkk, 2008, Perancangan

Kontrak dan Memorandum of Understanding (MoU), Jakarta, Sinar Grafika.

Shidarta, 2006, Hukum Perlindungan Konsumen Indonesia, Jakarta, Grasindo.

Soedikno Mertokusumo, 1984, Bunga Rampai Ilmu Hukum, Yogyakarta, Liberty.

Subekti, 1979, Hukum Perjanjian, Jakarta, Intermasa. 1990, Hukum Perjanjian, Ctk. Ke dua belas, Jakarta, PT. Intermasa. 